\title{
MELENGESTROL ACETATE ADMINISTRATION TO DAIRY HEIFERS AND PROGESTAGEN LEVELS IN THE PERIPHERAL BLOOD PLASMA*
}

\author{
J. H. BRITT $\dagger$ AND L. C. ULBERG \\ Reproductive Physiology Research Laboratory, \\ North Carolina State University, Raleigh
}

Received 20th July 1971, accepted 8th November 1971)

Oestrous synchronization in cattle has not received widespread acceptance because of a period of transitory infertility which occurs following progestagen withdrawal. This reduced fertility has been attributed to changes in the time required for sperm capacitation (Lauderdale \& Erickson, 1970), changes in the amount and physicochemical characteristics of cervical mucus (Johnson \& Ulberg, 1965; Hill, Lamond, Henricks, Dickey \& Niswender, 1971), changes in body temperature (Johnson \& Ulberg, 1965; Long, Nipper \& Vincent, 1969), reduced fertilization rate (Wagner, Veenhuizen, Gregory \& Tonkinson, 1968), and histochemical changes in the endometrium (Wordinger, Dickey \& Hill, 1970). All of these physiological aberrations can be attributed to hormonal changes. This experiment was conducted to determine changes in peripheral blood plasma progesterone concentration during and subsequent to oestrous synchronization with melengestrol acetate (MGA-The Upjohn Company) and to compare these changes with those occurring at comparable times during normal oestrous cycles.

Five nulliparous Jersey heifers, approximately 15 months old and weighing about $270 \mathrm{~kg}$, were used. They were observed for oestrus at least twice daily and the day of oestrus was designated as Day 0 . Each animal served as her own control for the experiment. During the oestrous cycle preceding the treatment period (pretreatment cycle), jugular vein blood samples were collected on Days $0,1,2,3,9,15,17$ and daily thereafter until the next oestrus. At least one oestrous cycle was allowed to elapse between the pretreatment control cycle and the initiation of MGA treatment. From Day 14 to Day 27 inclusive, each heifer received $1 \mathrm{mg}$ MGA daily. The MGA was given orally in a No. 10 gelatin capsule. Blood samples were collected from the peripheral system on Days 16, 19,22 and 25 of the treatment cycle and daily after treatment until oestrus. During the subsequent oestrous cycle (post-treatment cycle), blood samples were collected until the next oestrus according to the schedule for the pretreatment cycle.

The blood was collected into vessels containing a $10 \%$ solution of ethylenediaminetetraacetate and was immediately cooled and centrifuged at $6500 \mathrm{~g}$ for

\footnotetext{
* Paper No. 3510 of the Journal Series of the North Carolina State University Agricultural Experiment Station, Raleigh.

$\uparrow$ Present address: Department of Dairy Science, Michigan State University, East Lansing.
} 
$20 \mathrm{~min}$. The plasma was then decanted and stored at $-15^{\circ} \mathrm{C}$ until assay. The concentrations of progestagen, assumed to be progesterone, were determined by the competitive protein-binding assay described by Randel, Brown, Erb, Niswender \& Callahan (1971). Changes in gross ovarian morphology during the study were determined by regular palpations per rectum. The individual daily values for progesterone concentrations in the plasma were averaged and the mean for the five values on each day are reported in Table 1. The three sampling days immediately before oestrus in each cycle were designated as Days $-3,-2$ and -1 . In some cases, the individual values for Days -3 and -2 overlap with Day 17.

\section{TABLE 1}

PROGESTERONE LEVELS IN PERIPHERAL BLOOD PLASMA OF HEIFERS BEFORE, DURING AND AFTER

ADMINISTRATION OF MELENGESTROL AGETATE

\begin{tabular}{|c|c|c|c|}
\hline \multirow[b]{2}{*}{$\begin{array}{l}\text { Day of } \\
\text { cycle }\end{array}$} & \multicolumn{3}{|c|}{ Progesterone (ng/ml plasma) } \\
\hline & $\begin{array}{l}\text { Pretreatment } \\
\text { cycle }\end{array}$ & $\begin{array}{c}\text { Treatment } \\
\text { cycle }\end{array}$ & $\begin{array}{l}\text { Post-treatment } \\
\text { cycle }\end{array}$ \\
\hline $\begin{array}{r}\text { Oestrus } \\
1 \\
2 \\
3 \\
9 \\
15 \\
16 \\
17 \\
19 \\
22 \\
25 \\
28 \\
29 \\
-3 \ddagger \\
-2 \ddagger \\
-1 \ddagger\end{array}$ & $\begin{array}{l}0.5 \pm 0.4 \\
0.9 \pm 0.4 \\
0.4 \pm 0.3 \\
1.3 \pm 0.5 \\
2.5 \pm 0.8 \\
4.4 \pm 2.3 \\
\downarrow \\
4.3 \pm 0.7\end{array}$ & $\begin{array}{l}4.6 \pm 0.9^{*} \\
7.0 \pm 1.5^{*} \\
3.7 \pm 1.0^{*} \\
4.8 \pm 1.0^{*} \\
6.0 \pm 1.5 \dagger \\
7.7 \pm 1.5 \dagger \\
6.8 \pm 1.8 \\
4.6 \pm 1.0 \\
3.1 \pm 1.2\end{array}$ & $\begin{array}{l}0.4 \pm 0.2 \\
0.7 \pm 0.3 \\
1.1 \pm 0.6 \\
1.7 \pm 0.8 \\
3.8 \pm 1.3 \\
3.7 \pm 0.4 \\
2.2 \pm 1.0\end{array}$ \\
\hline
\end{tabular}

Each value is the mean of five observations. Values are expressed as means \pm S.E.

* Blood values during drug administration.

+1 and 2 days after the end of drug administration. \$ 3 days, 2 days and 1 day before oestrus.

During the pretreatment oestrous cycle, the average progesterone concentration increased from $0.5 \mathrm{ng} / \mathrm{ml}$ plasma at oestrus to $4.4 \mathrm{ng} / \mathrm{ml}$ on Day 15 and $4.3 \mathrm{ng} / \mathrm{ml}$ on Day 17 . Those values then decreased from 4.2 to $0.5 \mathrm{ng} / \mathrm{ml}$ during the 3 days preceding the next oestrus. The average progesterone concentration fluctuated between 3.7 and $7.7 \mathrm{ng} / \mathrm{ml}$ plasma during treatment and for 2 days following MGA withdrawal (Day 28 and Day 29). This occurred even though all corpora lutea had regressed to less than $10 \mathrm{~mm}$ in diameter by the 3rd day (Day 16) of MGA administration. These values agree with those reported by Hill et al. (1971). The average progesterone concentration then decreased from $6 \cdot 8$ to $3 \cdot 1 \mathrm{ng} / \mathrm{ml}$ plasma during the 3 days just preceding oestrus following MGA withdrawal. The mean progesterone concentration increased from $0.4 \mathrm{ng} / \mathrm{ml}$ on the day of oestrus to $3.8 \mathrm{ng} / \mathrm{ml}$ by Day 9 and $3.7 \mathrm{ng} / \mathrm{ml}$ on Day 15 of the 
post-treatment cycle. The average concentration then decreased from 3.4 to 0.8 $\mathrm{ng} / \mathrm{ml}$ during the 3 days preceding the oestrus after that cycle. The progesterone concentration on Day 17 of the cycle before treatment appears to be considerably higher than the comparable value for the cycle after treatment, but this is due to a shorter average cycle length for the animals after treatment $(19.2$ versus 20.4 days).

The major point of interest in these data is the changes in blood plasma progesterone concentration during the 3 days preceding the oestrus which occurs immediately following treatment as compared to the changes in these values which occur during the 3 days preceding the oestrus in both of the other two cycles. Henricks, Hill \& Dickey (1970) observed a higher incidence of fertilization failure and retardation in ova cleavage rate in heifers which had an average progesterone concentration of more than $2.8 \mathrm{ng} / \mathrm{ml}$ blood plasma during the 4 days before oestrus. The average concentration for the 3 days before the oestrus following treatment in this study was $4.8 \mathrm{ng} / \mathrm{ml}$, as compared to $2 \cdot 2$ and $2 \cdot 3 \mathrm{ng} / \mathrm{ml}$, respectively, for pretreatment and post-treatment cycles. The average values for all sampling days during the non-treated cycles agree with values for normal cows as reported by Shemesh, Ayalon \& Lindner (1968a, b), Snook, Saatman \& Hansel (1969), Davis, Hull \& Moody (1970) and Henricks, Dickey \& Niswender (1970).

Although observations made in this study, along with observations made by others, do not conclusively show that increased progesterone level before oestrus in progestagen-treated heifers resulted in lowered fertility, they do suggest an aberration in the hormone levels as oestrus approaches. These levels may be important factors affecting the first service conception rate in progestagen-synchronized animals.

This investigation was supported in part by the North Carolina Dairy Foundation and by The Upjohn Company.

\section{REFERENCES}

DAvis, D. P., Hull, M. W. \& Moody, E. L. (1970) Jugular vein and posterior vena cava plasma progesterone levels in cycling heifers. (Abstract). F. Anim. Sci. 31, 330.

Henricks, D. M., Dickey, J. F. \& Niswender, G. D. (1970) Serum luteinizing hormone and plasma progesterone levels during the estrous cycle and early pregnancy in cows. Biol. Reprod. 2, 346.

Henricks, D. M., Hill, J. R. \& DickeY, J. F. (1970) Relationship between plasma progesterone concentrations and early mortality in the cow. (Abstract). Proc. Soc. Study Reprod. Columbus, Ohio, 9-11 September.

Hill, J. R., JR, Lamond, D. R., Henricks, D. M., Dickey, J. F. \& Niswender, G. D. (1971) The effect of melengestrol acetate (MGA) on ovarian function and fertilization in beef heifers. Biol. Reprod. 4, 16.

Johnson, A. D. \& UlberG, L. C. (1965) Some physiological manifestations in the bovine estrous cycle during control with exogenous hormones. J. Anim. Sci. 24, 403.

Lauderdale, J. W. \& Ericsson, R. J. (1970) Physiological conditions affecting the ability of cattle uteri to influence the fertilizing capacity of sperm. Biol. Reprod. 2, 179 .

Long, C. R., Nipper, W. A. \& VincENT, C. K. (1969) Body temperature and estrous control of beef cattle. (Abstract). F. Anim. Sci. 29, 146.

Randel, R. D., Brown, B. L., Erb, R. E., Niswender, G. D. \& Callahan, C. J. (1971) Reproductive steroids in the bovine. II. Comparison of free-martins to fertile heifers. $\mathcal{F}$. Anim. Sci. 32, 318.

Shemesh, M., Ayalon, N. \& Lindner, H. R. (1968a) Early effect of conceptus on plasma progesterone level in the cow. F. Reprod. Fert. 15, 161. 
Shemesh, M., Ayalon, N. \& Lindner, H. R. (1968b) Plasma progesterone concentrations in dairy cows during the oestrous cycle. Refuah vet. $25,265$.

Snook, R. B., SaAtman, R. R. \& Hansel, W. (1969) Serum progesterone and luteinizing hormone levels throughout the bovine estrous cycle. (Abstract). Proc. Soc. Study Reprod. Davis, California, 8-10 September.

Wagner, J. F., Veenhutzen, E. L., Gregory, R. P. \& Tonkinson, L. V. (1968) Fertility in the beef heifer following treatment with 6-chloro $\Delta^{6}-17$ acetoxyprogesterone. 7 . Anim. Sci. 27, 1627.

Wordinger, R. J., Dickey, J. F. \& Hill, J. R., JR (1970) Effect of MGA on bovine endometrium. (Abstract). F. Anim. Sci. 31, 234. 